\title{
Are ants attracted to herbivorized leaves of Caryocar brasiliense Camb. (Caryocaraceae)?
}

\author{
Verônica Bernardino de S. Magalhães ${ }^{1}$ \& Viviane Gianluppi Ferro ${ }^{2 *}$ (]) \\ ${ }^{1}$ Universidade Federal de Goiás, Instituto de Ciências Biológicas, Graduação em Ecologia e Análise \\ Ambiental, Departamento de Ecologia, CEP 74001-970, Goiânia, GO, Brasil. \\ ${ }^{2}$ Universidade Federal do Rio Grande do Sul, Instituto de Biociências, Departamento de Zoologia, CEP \\ 91501970, Porto Alegre, RS, Brasil. \\ "Corresponding author: Viviane Gianluppi Ferro, e-mail: vivianegferro@gmail.com
} MAGALHÃES, V.B.S., FERRO, V.G. Are ants attracted to herbivorized leaves of Caryocar brasiliense Camb. (Caryocaraceae)? Biota Neotropica 20(3): e20200992. https://doi.org/10.1590/1676-0611-BN-2020-0992.

\begin{abstract}
Different profiles of secondary compounds are released by plants after herbivore attack. Many of these compounds are used by predators and parasitoids to locate herbivores that are damaging leaves. Such an induced indirect defense was tested with the Caryocar brasiliense-ant system in the dry season, when C. brasiliense has old leaves, and in the rainy season, when $C$. brasiliense has new leaves. A total of 20 plants were analyzed per season. Two opposite leaves of the same branch were selected for each plant. Approximately $40 \%$ of the area of one leaf was removed (treatment leaf) while the other leaf remained intact (control). The number of ants that visited each leaf was counted simultaneously for a period of 15 minutes and the mean difference in ant number was tested by paired t-test. The mean number of ants differed significantly between treatment and control only in the rainy season $(t=3.004, d f=19, p=0.007)$. This finding suggests the presence of induced defense in this system only when the leaves are young. The study supports the Optimal Defense Theory since young leaves of $C$. brasiliense with artificial damage attracted significantly more ants than leaves without damage and represents the first evidence of an induced defense mechanism in the $C$. brasiliense-ant system.
\end{abstract}

Keywords: ant-plant interaction; artificial herbivory; Cerrado; induced defense; Optimal Defense Theory.

\section{As formigas são atraídas por folhas herbivoradas de Caryocar brasiliense Camb. (Caryocaraceae)?}

Resumo: Diferentes compostos químicos são liberados pelas plantas após o ataque dos herbívoros. Muitos desses compostos são usados por predadores e parasitoides para localizar os herbívoros que estão injuriando as plantas. Esse tipo de defesa induzida indireta foi testada no sistema Caryocar brasiliense e formigas em duas estações: seca (quando $C$. brasiliense está com folhas maduras) e chuvosa (quando C. brasiliense está com folhas jovens). Nós analisamos 20 plantas por estação do ano. Em cada planta nós selecionamos duas folhas opostas de um mesmo ramo. Nós removemos cerca de $40 \%$ da área de uma das folhas, deixando a outra folha intacta. Nós mensuramos simultaneamente o número de formigas que visitaram cada tipo de folha por 15 min e analisamos a diferença entre o número de formigas em cada tipo de folha através de teste t pareado. Nós observamos diferença significativa no número de formigas que patrulham as folhas tratamento (com herbivoria artificial) e controle (sem hervivoria artificial) apenas na estação chuvosa ( $t=3,004, d f=19, p$ $=0,007)$. Isso sugere que existe defesa induzida nesse sistema somente quando as folhas são jovens. Nosso estudo corrobora a Teoria de Defesa Ótima já que apenas as folhas jovens de C. brasiliense com dano artificial atraíram significativamente mais formigas do que as folhas sem danos. Esta é a primeira vez que mecanismos de defesa induzida são observados no sistema $C$. brasiliense-formigas.

Palavras-chave: Cerrado; defesa induzida; herbivoria artificial; interação inseto-planta; Teoria da Defesa Ótima. 


\section{Introduction}

Plant defense strategies against herbivores can be categorized as either direct or indirect. Direct defenses negatively affect herbivore metabolism via toxic compounds and digestibility reducers (Speight et al. 1999, Marquis 2012) whereas indirect defenses occur when the plant attracts other insects that can reduce herbivore damage (Bixenmann et al. 2013). In the latter strategy, the plant provides chemical cues or rewards (food and/or shelter) to attract predators and parasitoids of the herbivores (Boege \& Marquis 2005).

Leaves naturally release volatile organic compounds (VOCs) during their development. However, when damage occurs, usually due to herbivores, some plants quantitatively and/or qualitatively change their VOC profile (Paré \& Tumlinson 1999, Marquis 2012). Such new VOC profiles may inhibit oviposition or reduce herbivore performance (induced direct defense), or act as a cue for predators and parasitoids to locate herbivores that are causing damage (induced indirect defense) (Turlings et al. 1995, Paré \& Tumlinson 1999, Carroll et al. 2006, Heil 2014). Kost \& Heil (2006) demonstrated that VOCs released by damage plants could be recognized by undamaged neighboring co-specific plants, acting as a trigger for increased secretion of extrafloral nectar.

Ants are known to respond to VOCs of host plants (Brouat et al. 2000), which generally attract ants to damaged leaves (Schatz et al. 2009). Three VOCs - methyl salicylate, 2E hexen-1-ol and hexanal - were detected in damaged leaves of Leonardoxa africana (Fabaceae) (Schatz et al. 2009), as well as in Macaranga (Euphorbiaceae) (Inui \& Itioka 2007). Most studies that have tested the effectiveness of chemical signals for attracting ants after plant damage used myrmecophytic systems, such as Hirtella myrmecophila (Chrysobalanaceae)-Allomerus octoarticulatus ants (Romero \& Izzo 2004), Tachigali myrmecophila (Fabaceae)Pseudomyrmex concolor ants (Pacheco \& Del-Claro 2018), Piper (Piperaceae)-Pheidole ants (Mayer et al. 2008), and Cecropia (Urticaceae)-Azteca ants (Agrawal 1998). Analysis of VOCs after damage to myrmecophytic and non-myrmecophytic plants showed that the chemical profiles differed with only the myrmecophytic species (Mayer et al. 2008). Unfortunately, studies of VOCs of non-myrmecophytic plants are scarce.

Caryocar brasiliense Camb. (Caryocaraceae), known locally as "pequizeiro", is a typical tree of the Brazilian Cerrado. It is a semideciduous plant that loses some of its leaves during the dry season (May to July) (Araujo 1995), and grows young leaves during the beginning of the rainy season (September to March) (Vilela et al. 2008). Flowering starts soon after the expansion of young leaves, with fruiting occurring from October to February (Vilela et al. 2008).

According to Oliveira \& Freitas (2004) and Oliveira et al. (2012), the main herbivores of C. brasiliense are: (1) Eunica bechina (Lepidoptera: Nymphalidae), whose larvae feed on young leaves; (2) Edesa rufomarginata (Hemiptera: Pentatomidae), which feeds on plant sap; (3) Prodiplosis floricola (Diptera: Cecidomyiidae), which the larvae feed on flower buds; and (4) wasps (Hymenoptera: Chalcidoidea), whose larvae induce gall formation in leaves and branches. Plants of C. brasiliense are constantly visited (day and night) by more than 30 species of ants, especially of the genera Camponotus and Cephalotes, which feed on secretions of extrafloral nectaries (EFNs) of flower buds and young leaves (Oliveira \& Brandão 1991).
Although several studies have verified the importance of ants as a constitutive defense in C. brasiliense (e.g., Oliveira 1997, Oliveira $\&$ Freitas 2004), the existence of an induced indirect defense in this system has not been tested. This study aimed to determine if this type of defense occurs in the $C$. brasiliense-ant system. Specifically, the following questions were addressed: (1) do C. brasiliense leaves with artificial damage attract more ants than leaves without damage? (2) Are young leaves more attractive to ants than mature leaves?

\section{Material and Methods}

Experiments were conducted in Emas National Park (ENP) located

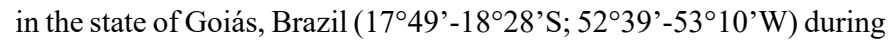
the dry (July 2012) and rainy (September 2012) seasons with 20 Caryocar brasiliense plants per season. The plants had mature leaves and considerable herbivory during the dry season (Figure 1a), while EFNs were active and young leaves did not have signs of herbivory during the rainy season (Figure 1b).

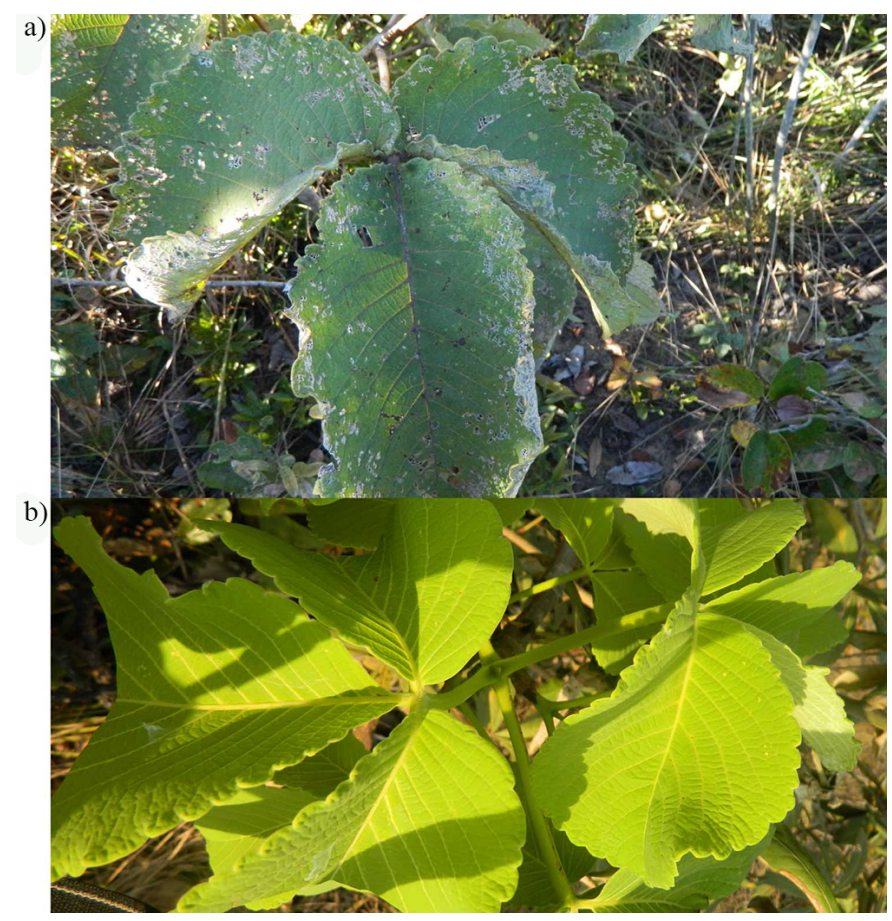

Figure 1. Leaves of Caryocar brasiliense in the dry (a) and in the rainy (b) seasons.

A total of 40 C. brasiliense trees of similar height, architecture and herbivory level were selected for study. One branch with fully expanded leaves and minimal herbivore damage was selected in each plant, on which two opposite leaves were identified. Approximately $40 \%$ of the leaf area of one leaf was removed with a scissors (treatment leaf, with artificial herbivory), while the other leaf remained intact (control leaf, without artificial herbivory). Both leaves were shaken prior to the start of the experiment to assure no ants were present.

The number of ants visiting paired leaves was counted simultaneously for period of 15 minutes. Ants that were observed visiting the experiment leaves were manually collected with a forceps, preserved in $70 \%$ alcohol, and identified to morphospecies. Difference in mean number of ants was tested by paired t-test, considering plants as sample units. 


\section{Results}

Nine morphospecies of five subfamilies of ants occurred on the leaves of $C$. brasiliense during our study. Three of the morphospecies occurred only in the dry season, two only in the rainy season and four in both seasons. Different morphospecies of ants patrolled the experimental plants, but in most cases only one morphospecies was found on a plant. Camponotus was the most diverse genus with three morphospecies (Table 1).

Table 1. Ant species (Hymenoptera: Formicidae) that patrolled plants of Caryocar brasiliense in Emas National Park in the dry season (July) and in the rainy season (September) of 2012.

\begin{tabular}{|c|c|c|c|}
\hline \multicolumn{2}{|c|}{ Taxon } & \multicolumn{2}{|c|}{ Season } \\
\hline Subfamily & Morphospecies & Dry & Rainy \\
\hline \multirow{2}{*}{ Dolichoderinae } & Azteca sp. 1 & $\mathrm{X}$ & $\mathrm{X}$ \\
\hline & Azteca sp. 2 & $\mathrm{X}$ & $\mathrm{X}$ \\
\hline \multirow{3}{*}{ Formicinae } & Camponotus sp. 1 & $\mathrm{X}$ & $\mathrm{X}$ \\
\hline & Camponotus sp. 2 & $\mathrm{X}$ & $\mathrm{X}$ \\
\hline & Camponotus sp. 3 & $\mathrm{X}$ & \\
\hline \multirow[t]{2}{*}{ Myrmicinae } & Cephalotes sp. 1 & $\mathrm{X}$ & \\
\hline & Crematogaster sp. 1 & $\mathrm{X}$ & \\
\hline Ponerinae & Pachycondyla sp. 1 & & $\mathrm{X}$ \\
\hline Pseudomyrmecinae & Pseudomyrmex sp. 1 & & $\mathrm{X}$ \\
\hline
\end{tabular}

There was no significant difference in the mean number of ants between treatment and control leaves in the dry season $(\mathrm{t}=1.011$, $\mathrm{df}$ $=19, \mathrm{p}=0.325 ;$ mean $=5.75$ and 4.20 , respectively) (Figure 2a), but there was significantly more ants on treatment $($ mean $=4.15)$ than control (mean $=2.10)$ leaves in the rainy season $(t=3.004, \mathrm{df}=19$, $\mathrm{p}=0.007)$ (Figure 2b).

\section{Discussion}

Although the mean number of ants on treatment leaves was greater than that of control leaves in both seasons, the difference was only significant in the rainy season, suggesting induced defense in this system only when leaves are young.

Herbivory of young leaves tends to have a greater effect on plant fitness than does herbivory on mature leaves (Jurik \& Chabot 1986). In addition, young leaves have not yet contributed enough in terms of photosynthetic production to offset the high costs of their construction (Radhika et al. 2008). Because young leaves are softer and more nutritious than mature leaves they tend to be more attractive to herbivores (Kursar \& Coley 2003). For example, Coley \& Barone (1996) found that $70 \%$ of leaf herbivory of rainforest plants occurs during leaf expansion.
The Optimal Defense Theory (ODT) predicts that resource allocation for defense should be higher in the most valuable plant parts (measured in terms of reduction in fitness by its removal) and parts more likely to be damaged by herbivores (Mckey 1974, Zangerl \& Bazzaz 1992). Many studies have found young leaves to have higher concentrations and a greater diversity of secondary compounds than mature leaves (e.g., van Dam et al. 1995, Read et al. 2003), which supports ODT. Radhika et al. (2008), for example, applied jasmonic acid to castor bean leaves and found that the release of volatiles and extrafloral nectary secretion was higher in young than in old leaves. The present study also supports ODT, since only the young leaves of C. brasiliense with artificial herbivory attracted significantly more ants than leaves without artificial herbivory. Likewise, Pacheco \& Del-Claro (2018) also detected a higher number of Pseudomyrmex concolor ants on young damaged leaves of Tachigali myrmecophila in the Amazon.

Although the present study did not analyze the composition and concentration of leaf compounds, the response of ants (higher recruitment in damaged young leaves) indicates chemical signaling by the plant after damage, suggesting that induced defense is only evident when leaves are young. The present results may be an underestimation because of the type of artificial herbivory employed (damage by cutting with scissors), because some studies have shown that natural herbivory elicits greater defense induction than mechanical damage (Hartley \& Lawton 1987, Massey, Ennos \& Hartley 2007, Quigley \& Anderson 2014). Oral secretions provide herbivore-specific cues for defense induction by many insects (Alborn et al. 1997, Tian et al. 2012). Components of insect saliva, plant cell wall fragments and other cues create a signal cascade that triggers a defense response that increases concentrations of secondary metabolites (Stam et al. 2014). While counting ants in the present study, many were observed touching the region where the leaves had been cut with their antennae and/or mandibles, suggesting that liquid substances, in addition to volatile compounds, may also be acting as signals for the ants.

Plants of C. brasiliense are constantly visited by ants that feed on extrafloral secretions of flower buds and young leaves (Oliveira $\&$ Brandão 1991). Several studies have shown that ants reduce herbivore damage to C. brasiliense (e.g., Oliveira \& Freitas 2004), thereby increasing plant fitness (Oliveira 1997). The observations of the present study suggest that there is induced defense in young leaves of $C$. brasiliense and represent the first evidence of an induced defense mechanism in the $C$. brasiliense-ant system. Additional studies, including quantitative and qualitative chemical analyses, are recommended to further investigate the role of this type of defense in $C$. brasiliense. Additional research on VOCs in other non-myrmecophytic systems are needed. Such studies could lead to greater insight into whether particular chemical traits are associated with the evolution of ant-plant relationships. 
MAGALHÃES, V.B.S. and FERRO, V.G.

a)

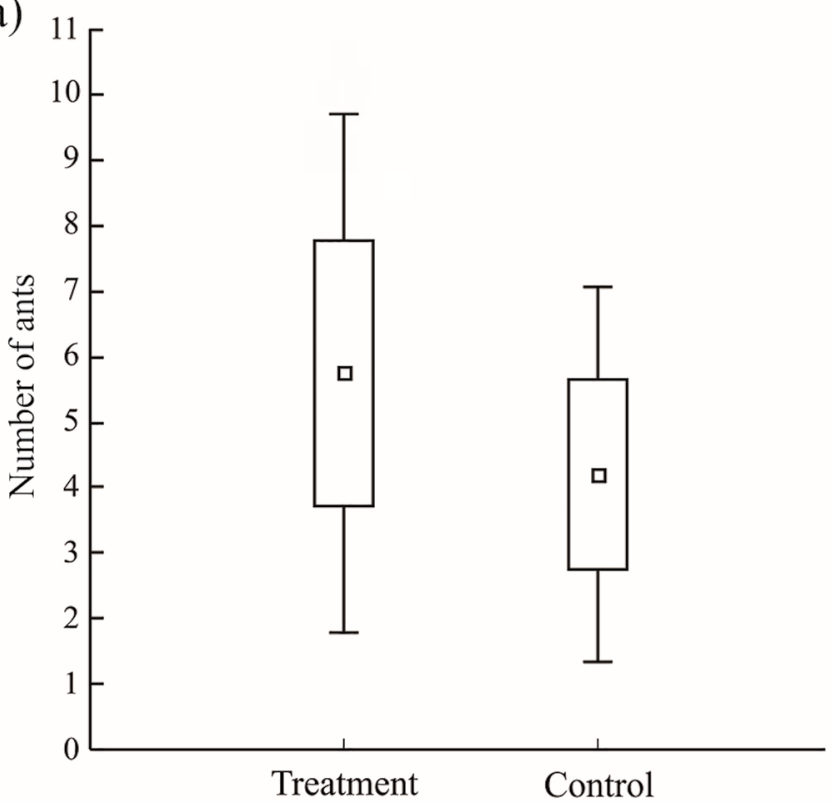

b)

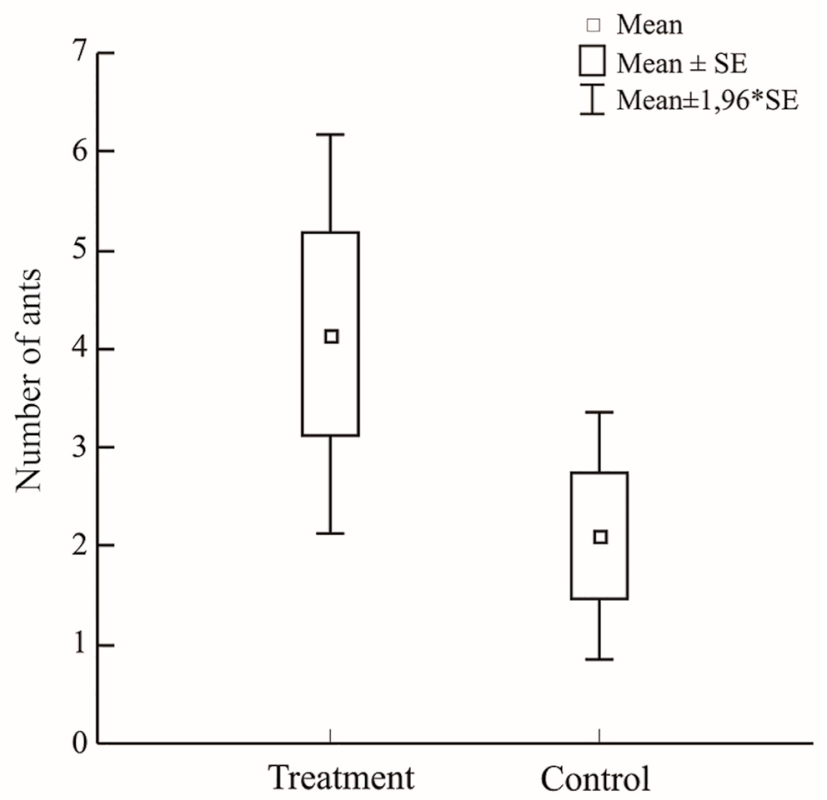

Figure 2. Mean number of ants that visited treatment (with artificial herbivory) and control (without artificial herbivory) leaves of Caryocar brasiliense in (a) the dry season $(\mathrm{t}=1.011, \mathrm{df}=19, \mathrm{p}=0.325)$ and $(\mathrm{b})$ in the rainy season $(\mathrm{t}=3.004 ; \mathrm{df}=19 ; \mathrm{p}=0.007)$. Twenty plants were sampled in each season.

\section{Acknowledgements}

We would like to thank Vidal Carrascosa, Carolina Moreno, Amanda Rosa e Karen Neves for help in the fieldwork and ant identifications. The first author received a student fellowship from Conselho Nacional de Desenvolvimento Científico e Tecnológico (CNPq). This study was funded by Site 13 (Parque Nacional das Emas) of the Brazilian Long Term Ecological Research Network (CNPq, 558187/2009-9).

\section{Authors Contributions}

Verônica Bernardino de S. Magalhães: Contributed with data acquisition, data analyses and manuscript preparation.

Viviane Gianluppi Ferro: Contributed with data acquisition, data analyses and manuscript preparation.

\section{Conflict of Interest}

The authors declare that they have no conflict of interest related to the publication of this manuscript.

\section{References}

AGRAWAL, A.A. 1998. Leaf damage and associated cues induced aggressive ant recruitment in a neotropical ant-plant. Ecology 79(6): 2100-2112.

ALBORN, H.T., TURLINGS, T.C.J., JONES, T.H., STENHAGEN, G., LOUGHRIN, J.H. \& TUMLINSON, J.H. 1997. An elicitor of plant volatiles from beet armyworm oral secretion. Science, 276(5314): 945-949.

ARAUJO, F.D. 1995. A review of Caryocar brasiliense (Caryocaraceae), an economically valuable species of the Central Brazilian Cerrados. Econ. Bot. 49(1): 40-48.

BIXENMANN, R.J., COLEY, P.D. \& KURSAR, T.A. 2013. Developmental changes in direct and indirect defenses in the young leaves of the neotropical tree Inga (Fabaceae). Biotropica 45(2): 175-184.
BOEGE, K. \& MARQUIS, R.J. 2005. Facing herbivory as you grow up: the ontogeny of resistance in plants. Trends Ecol. Evol. 20(8): 441-448.

BROUAT, C., MCKEY, D., BESSIERE, J.M., PASCAL, L. \& HOSSAERTMCKEY, M. 2000 Leaf volatile compounds and the distribution of ant patrolling in an ant-plant protection mutualism: preliminary results on Leonardoxa (Fabaceae: Caesalpinioideae) and Petalomyrmex (Formicidae: Formicinae). Acta Oecol. 21(6): 349-357.

CARROLL, M.J., SCHMELZ, E.A, MEAGHER, R.L. \& TEAL, P.E. 2006. Attraction of Spodoptera frugiperda larvae to volatiles from herbivoredamaged maize seedlings. J. Chem. Ecol. 32(9): 1911-1924.

COLEY, P.D. \& BARONE, J.A. 1996. Herbivory and plant defenses in tropical forests. Annu. Rev. Ecol. Syst. 27: 305-335.

HARTLEY, S.E. \& LAWTON, J.H. 1987. Effects of different types of damage on the chemistry of birch foliage, and the responses of birch feeding insects. Oecologia, 74(3): 432-437.

HEIL, M. 2014. Herbivore-induced plant volatiles: targets, perception and unanswered questions. New Phytol. 204: 297-306.

INUI, Y. \& ITIOKA, T. 2007. Species-specific leaf volatiles compounds of obligate Macaranga myrmecophytes and host-specific aggressiveness of symbiotic Crematogaster ants. J. Chem. Ecol. 33(11): 2054-2063.

JURIK, T.W. \& CHABOT, B.F. 1986. Leaf dynamics and profitability in wild strawberries. Oecologia 69: 296-304.

KOST, C. \& HEIL, M. 2006. Herbivore induced plant volatiles induce an indirect defence in neighbouring plants. J. Ecol. 94: 619-628.

KURSAR, T.A. \& COLEY, P.D. 1991. Nitrogen content and expansion rate of young leaves of rain forest species: implications for herbivory. Biotropica 23(2): 141-150.

MARQUIS, R.J. 2012. Uma abordagem geral das defesas das plantas contra a ação dos herbívoros. In Ecologia das Interações Plantas-Animais. Uma abordagem ecológico-evolutiva (K. Del-Claro \&H.M. Torezan-Silingardi, eds). Technical Books, Rio de Janeiro, p. 53-66.

MASSEY, F.P., ENNOS, A.R. \& HARTLEY, S.E. 2007. Herbivore specific induction of silica-based plant defences. Oecologia, 152(4): 677-683.

MAYER, V., SCHABER, D. \& HADACEK, F. 2008. Volatiles of myrmecophytic Piper plants signal stem tissue damage to inhabiting Pheidole ant-partners. J. Ecol. 96(5): 962-970.

MCKEY, D. 1974. Adaptive patterns in alkaloid physiology. Am. Nat. 108(961): 305-320. 
OLIVEIRA, P.S. \& BRANDÃO, C.R.F. 1991. The ant community associated with extrafloral nectaries in Brazilian cerrados. In Ant-plant interactions (D.F. Cutler \& C.R. Huxley, eds). Oxford University Press, Oxford, p.198-212.

OLIVEIRA, P.S. 1997. The ecological function of extrafloral nectaries: herbivore deterrence by visiting ants and reproductive output in Caryocar brasiliense (Caryocaraceae). Funct. Ecol. 11(3): 323-330.

OLIVEIRA, P.S.\& FREITAS, A.V.L. 2004. Ant-plant-herbivore interactions in the neotropical cerrado savanna. Naturwissenschaften 91(12): 557-570.

OLIVEIRA, P.S., SENDOYA, S.F. \& DEL-CLARO, K. 2012. Defesas bióticas contra herbívoros e plantas do cerrado: interações entre formigas, nectários extraflorais e insetos trofobiontes. In Ecologia das Interações PlantasAnimais. Uma abordagem ecológico-evolutiva (K. Del-Claro \&H.M. Torezan-Silingardi, eds). Technical Books, Rio de Janeiro, p.155-165.

PACHECO, P.S.M. \& DEL-CLARO, K. 2018. Pseudomyrmex concolor Smith (Formicidae: Pseudomyrmecinae) as induced biotic defence for host plant Tachigali myrmecophila Ducke (Fabaceae: Caesalpinioideae). Ecol. Entomol. 43(6): 782-793.

QUIGLEY, K.M. \& ANDERSON, T.M. 2014. Leaf silica concentration in Serengeti grasses increases with watering but not clipping: insights from a common garden study and literature review. Front. Plant Sci., 5: 568.

PARÉ, P.W. \& TUMLINSON, J.H. 1999. Plant volatiles as a defense against insect herbivores. Plant Physiol. 121(2): 325-331.

RADHIKA, V., KOST, C., BARTRAM, S., HEIL, M. \& BOLAND, W. 2008. Testing the optimal defence hypothesis for two indirect defences: extraforal nectar and volatile organic compounds. Planta 228(3): 449-457.

READ, J., GRAS, E., SANSON, G.D., CLISSOLD, F. \& BRUNT, C. 2003. Does chemical defence decline more in developing leaves that become strong and tough at maturity? Aust. J. Bot. 51(5): 489-496.

ROMERO, G.Q. \& IZZO, T.J. 2004 Leaf damage induces ant recruitment in the Amazonian ant-plant Hirtella myrmecophila. J. Trop. Ecol. 20(6): 675-682.
SCHATZ, B., DJIETO-LORDON, C., DORMONT, L., BESSIÈRE, J.M., MCKEY, D. \& BLATRIX, R. 2009. A simple non-specific chemical signal mediates defence behaviour in a specialised ant-plant mutualism. Curr. Biol. 19(9): R361-R362.

SPEIGHT, M.R., HUNTER, M.D. \& WATT, A.D. 1999. Ecology of Insects: concepts and applications. Wiley-Blackwell, Singapore.

STAM, J.M., KROES, A., LI, Y., GOLS, R., VAN LOON, J.J.A., POELMAN, E.H. \& DICKE, M. 2014. Plant interactions with multiple insect herbivores: From community to genes. Annu. Ver. Plant Biol., 65: 689-713.

TIAN, D., PEIFFER, M., SHOEMAKER, E., TOOKER, J., HAUBRUGE, E., FRANCIS, F., LUTHE, D.S \& FELTON, G.W. 2012. Salivary glucose oxidase from caterpillars mediates the induction of rapid and delayedinduced defenses in the tomato plant. PLoS ONE, 7(4): e36168.

TURLINGS, T.C.J., LOUGHRIN, J.H., MCCALL, P.J., RÖSE, U.S., LEWIS, W.J. \& TUMLINSON, J.H. 1995. How caterpillar-damaged plants protect themselves by attracting parasitic wasps. Proc. Natl. Acad. Sci. USA 92(10): 4169-4174.

VAN DAM, N.M., WITTE, L., THEURING, C. \& HARTMANN, T. 1995. Distribution, biosynthesis and turnover of pyrrolizidine alkaloids in Cynoglossum officinale. Phytochemistry 39(2): 287-292.

VILELA, G.F., CARVALHO, D. \& VIEIRA, F.A. 2008. Fenologia de Caryocar brasiliense Camb. (Caryocaraceae) no Alto Rio Grande, Sul de Minas Gerais. Cerne 14(4): 317-329.

ZANGERL, A.R. \& BAZZAZ, F.A. 1992. Theory and pattern in plant defense allocation. In Plant resistance to herbivores and pathogens, ecology, evolution and genetics (R. Fritz \& E. Simms, eds.). University of Chicaco Press, Chicago, p.363-391.
Received: 03/03/2020

Revised: 20/05/2020

Accepted: 06/07/2020

Published online: 03/08/2020 